\title{
UV SPECTRAL FEATURES OF POLY(PROPYLENE IMINE) DENDRIMERS
}

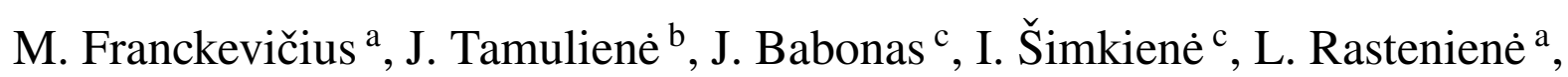 \\ A. Kulbickas \\ ${ }^{a}$ Liquid Crystals Laboratory, Vilnius Pedagogical University, Studentu 39, LT-08601 Vilnius, Lithuania \\ E-mail: marius.franckevicius@vpu.lt \\ ${ }^{\mathrm{b}}$ Vilnius University Institute of Theoretical Physics and Astronomy, A. Goštauto 12, LT-01108 Vilnius, Lithuania \\ ${ }^{\mathrm{c}}$ Semiconductor Physics Institute, Center for Physical Sciences and Technology, A. Goštauto 11, LT-01108 Vilnius, Lithuania
}

Received 21 February 2011; revised 2 September 2011; accepted 21 September 2011

\begin{abstract}
The UV optical spectra of amine terminated poly(propylene-imine) (PPI) dendrimers of generations G1 to G5 were investigated experimentally. The occurrence of double band at 270-290 $\mathrm{nm}$ in absorption spectra of amine terminated dendrimer and the dependence of the spectra on the generation number and concentration in dichloromethane solution were discussed. The lineshape of double band was similar in the sequence G1 to G5, though some redistribution of the intensity of components was observed. A linear dependence of the absorbance in the double band was determined in the solutions at low concentrations of order $1 \cdot 10^{-5} \mathrm{M}$. Experimental data have indicated that double band is caused by several optical transitions related to the core electronic excitations. A significant Rayleigh light scattering was found for higher dendrimer generations.
\end{abstract}

Keywords: PPI $\mathrm{NH}_{2}$-terminated dendrimers, optical absorbance, light scattering

PACS: $33.15 . \mathrm{Bh}, 33.20 . \mathrm{Lg}$

\section{Introduction}

Dendrimers are well known monodispersive organic macromolecules, possessing spherical three dimensional branched structures. Special interest is focused on pure poly(poropylene-imine) dendrimers, which are the parent molecules of a large dendrimer family. The structural modifications of PPI dendrimers allow one to expect the formation of new materials with distinct physical properties [1]. The dendrimers, which have been functionalized with different types of chromophore groups, have shown unusual photophysical properties [2, 3]. Modified PPI dendrimers can be used as catalytic agents to control the growth of metal nanoparticles [4]. In biomedical applications, the dendrimers are promising materials in drug delivery systems [5, 6]. Also, differently modified dendrimer structures open new possibilities for scientific investigations [7] and applications in various industrial fields [8]. For instance, due to particular structural features, dendrimers are considered [9, 10] as efficient components in the solar cells. Therefore, the spectroscopic studies [11,12] and analysis of electronic excitations are the pressing problems in scientific studies of dendrimers.
To our knowledge, few spectroscopic data have been published concerning to the electronic excitation of the PPI dendrimer interior.

Amine terminated PPI dendrimers possess a regular structure starting from 1,4-diaminobutane (DAB) core molecule $\mathrm{NH}_{2}\left(\mathrm{CH}_{2}\right)_{4} \mathrm{NH}_{2}$ to which four propyleneamine monomers $\mathrm{C}_{3} \mathrm{H}_{8} \mathrm{~N}$ are added in the first generation G1 [13]. The aim of the present work was to study the main regularities in the optical properties of $\mathrm{NH}_{2}$-terminated PPI dendrimers of generations G1 to G5. Fine structure of UV-vis spectra was analysed in order to reveal the particular features which are useful for a deeper understanding of electronic excitations in dendrimers.

\section{Experiment}

Commercially available (Sigma-Aldrich) amine $\left(\mathrm{NH}_{2}\right)$ terminated PPI dendrimers of generations $\mathrm{G} 1 \ldots$ G5 were studied by spectroscopic technique in the UV-vis spectral range. The gel-like substance of dendrimers was dissolved in dichloromethane. The obtained solutions ( $\mathrm{pH} 8$ ) for generations $\mathrm{G} 1$ and $\mathrm{G} 2$ were 
transparent whereas significant light scattering was observed for G4 and G5. The transmittance of freshlyprepared solutions did not change during several hours.

The optical spectra of amine terminated dendrimer solutions in dichloromethane were measured in a UVvis spectral range by means of a standard spectrophotometer (Perkin Elmer, Lambda 19). The parallel-walls quartz cuvettes of thickness up to $1 \mathrm{~cm}$ were used for spectroscopic investigations.

\section{Results and discussion}

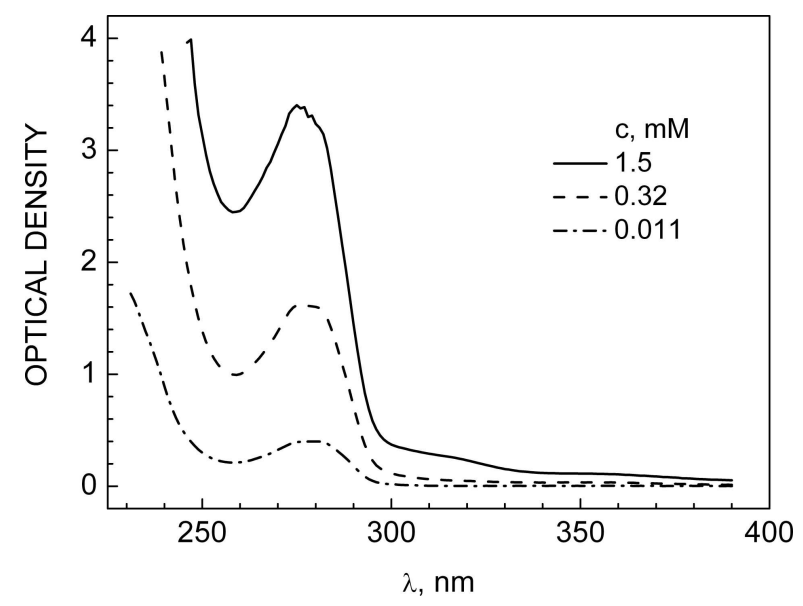

Fig. 1. Spectral dependence of the optical density of PPI amine terminated dendrimer (G1) solutions in dichloromethane at various molar concentrations $c$.

Typical spectra of the optical density for G1 generation of amine terminated PPI dendrimer solutions in dichloromethane at various molar concentrations are presented in Fig. 1. The spectra characterize the total transmittance loss due to the absorption and scattering of light when passing the dendrimer solution. The absorption band at $270-290 \mathrm{~nm}$ is quite well resolved. The band intensity was found to increase linearly with an increase of the dendrimer molar concentration at low concentrations of order $1 \cdot 10^{-5} \mathrm{M}$. A weak broad peak at $\sim 315 \mathrm{~nm}$ was also detected at higher dendrimer concentrations. An occurrence of the absorption in the long wavelength region at $360 \mathrm{~nm}$ has been also noticed in the solutions of amine $\left(-\mathrm{NH}_{2}\right)$ and carboxylate $\left(-\mathrm{COO}^{-}\right)$terminated [poly(amidoamine)] (PAMAM) dendrimers at higher concentrations $\left(8.6 \cdot 10^{-5} \mathrm{M}\right)$ [14]. Below, we shall pay the main attention to the regularities in the optical spectra related to the peak at 270 $290 \mathrm{~nm}$.

The variation of the optical spectra of amine terminated PPI dendrimers of various generations is illus-

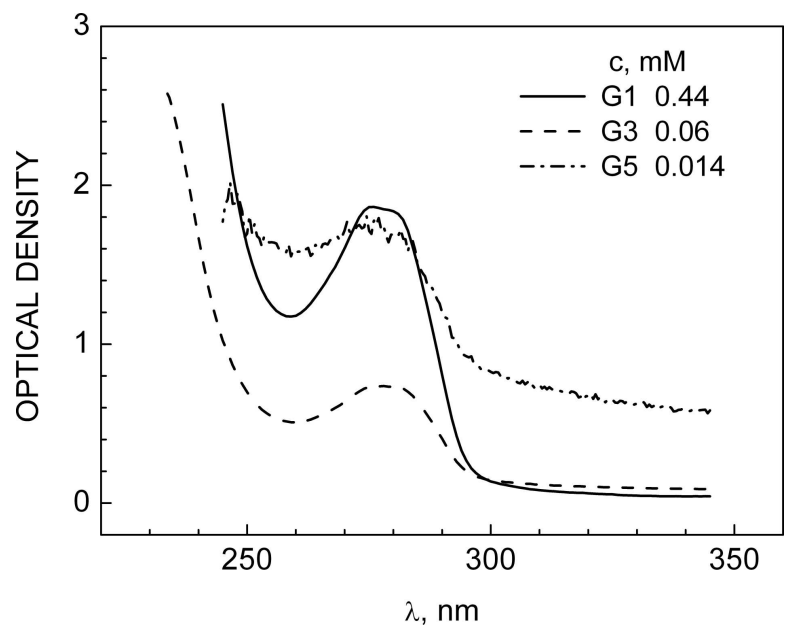

Fig. 2. Spectral dependence of the optical density of PPI amine terminated dendrimer solutions in dichloromethane at constant weight concentration $0.1 \mathrm{mg} / \mathrm{ml}$ corresponding to various mole concentrations $c$ for generations G1, G3, and G5.

trated in Fig. 2. The spectra of solutions of the same weight concentration $(0.1 \mathrm{mg} / \mathrm{ml})$ and hence of various mole concentrations are shown for generations G1, G3, and G5. As in Fig. 1, the optical density has been measured in transmission mode and corresponds to the extinction represented by the contributions of both absorption and light scattering. As is seen in Fig. 2, at longer wavelengths $(\lambda>330 \mathrm{~nm})$ the transmission losses are caused by dominating scattering.

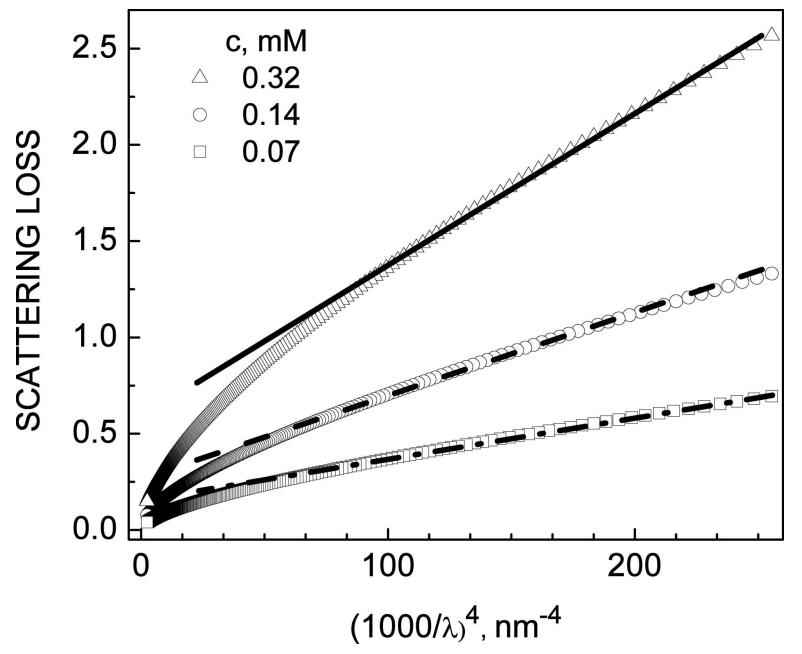

Fig. 3. Scattering loss, i.e., the optical density with absorption contribution excluded, versus $\lambda^{-4}$ at various molar concentrations of amine terminated PPI dendrimer (G5) solutions in dichloromethane.

The influence of light scattering increased substantially for larger generations G4 and G5. The dominating contribution of light scattering for dendrimers solution of generation G5 is clearly illustrated in Fig. 3, 
in which the losses due to absorption have been excluded. As seen there, the spectral dependence of scattering loss agrees well with Rayleigh scattering law. A linear dependence of scattering loss versus $\lambda^{-4}$ was observed in a wide spectral range with the slope increasing for higher dendrimer concentrations, though some influence of background absorption was still evident. An increase of light scattering in dendrimer solutions of higher generations is well understood taking into account a corresponding increase of viscosity [15] and the phase behaviour in amine terminated dendrimer solutions [16].

For a spherical particle of the diameter a, which is smaller by several orders of magnitude than the wavelength $\lambda$ of incident electromagnetic radiation, the intensity $I_{\mathrm{S}}$ of light scattered from a beam of unpolarized light of intensity $I_{\mathrm{i}}$ is given by a well-known formula for Rayleigh scattering [17]:

$$
I_{\mathrm{s}}=\frac{16 \pi^{4} a^{6}}{r^{2}} \frac{1}{\lambda^{4}}\left|\frac{m^{2}-1}{m^{2}+2}\right|\left(1+\cos ^{2} \theta\right) I_{\mathrm{i}},
$$

where $m$ is the refractive index of the particle, $\theta$ is the

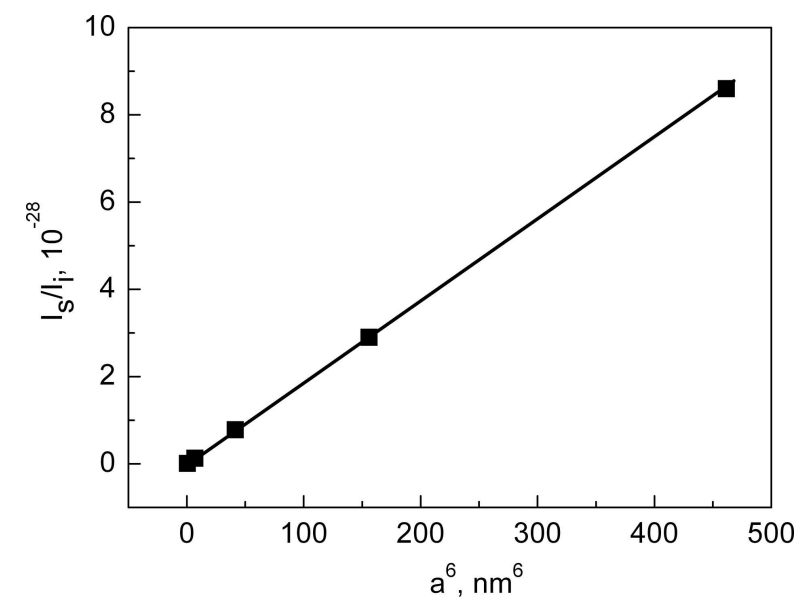

Fig. 4. Relative intensity $I_{\mathrm{s}} / I_{\mathrm{i}}$ of Rayleigh scattering calculated according to (1) versus $a^{6}$ (where $a$ is the diameter of dendrimer) for PPI dendrimers of generations G1 to G5 in dichloromethane at

$$
\lambda=400 \mathrm{~nm} \text {. }
$$

scattering angle, and $r$ is the distance to the particle. Taking into account the radius of the particles for PPI dendrimer generations G1 to G5 [18], the relative intensity of Rayleigh scattering (1) was simulated using the MiePlot v. 4.2 software [19]. The calculated results of the Rayleigh scattering at the $400 \mathrm{~nm}$ by dendrimer particles are shown in Fig. 4. The simulated linear dependence is in agreement with the experimentally observed light scattering data.

The fine structure of the absorption band at 270 $290 \mathrm{~nm}$ for PPI dendrimers was analysed in the model

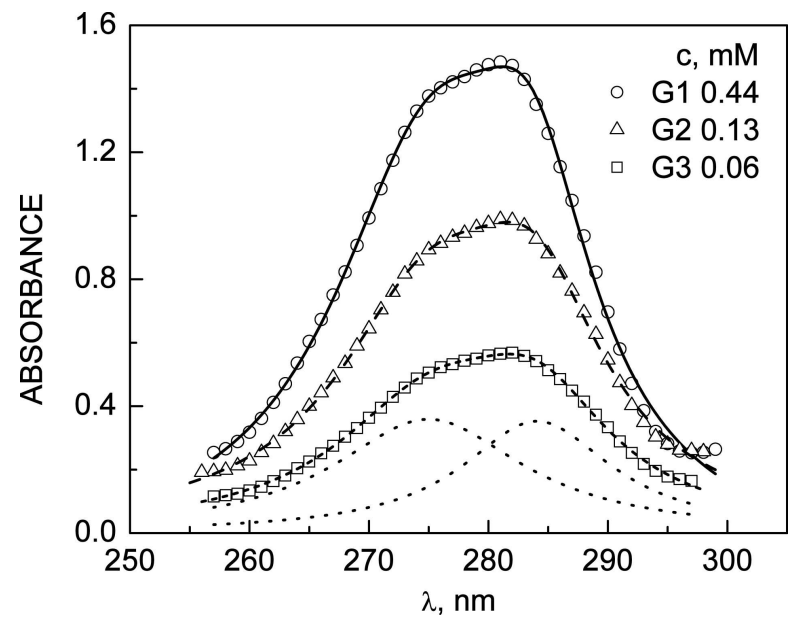

Fig. 5. Experimental (points) and simulated (curves) absorbance spectra, i. e., the optical density with the scattering contribution excluded, of amine terminated PPI dendrimers of generations G1, G2, and $\mathrm{G} 3$ at constant weight concentration $0.1 \mathrm{mg} / \mathrm{ml}$ corresponding to various mole concentrations $c$. The contribution of two components is shown for G3 generation.

of Lorentzian-type lines. In this spectral region, two peaks were clearly resolved (Fig. 5). The Lorentziantype components of 20 and $14 \mathrm{~nm}$ width were observed at 275 and $284 \mathrm{~nm}$, respectively. It should be noted that double band structure was also determined in the absorption spectra of a series of diamino-alkanes [20].

The line shape of components in the double band was similar for all dendrimer generations. Figure 6 illustrates the fine structure of the double absorption band of amine terminated PPI dendrimer solutions. As seen there, the double band structure is close for various generations under consideration at the same molar concentrations. Thus, it is reasonable to assume that the excitation involving core is responsible for the absorption in the UV double band.

\section{Conclusions}

The absorption spectra of amine terminated PPI dendrimers of generations G1...G5 dissolved in dichloromethane were measured and analysed. The double band has been observed in the wavelength range from 270 to $290 \mathrm{~nm}$, which is typical of amine terminated PPI dendrimers. The fine structure of the double band is similar for all generations under investigation. It is also found that the role of the Rayleigh-type light scattering significantly increases for higher generations G3...G5 in agreement with the regularities in the size of dendrimer molecules. Based on the quantum-chemical calculations, the theoretical interpretation of amine termi- 

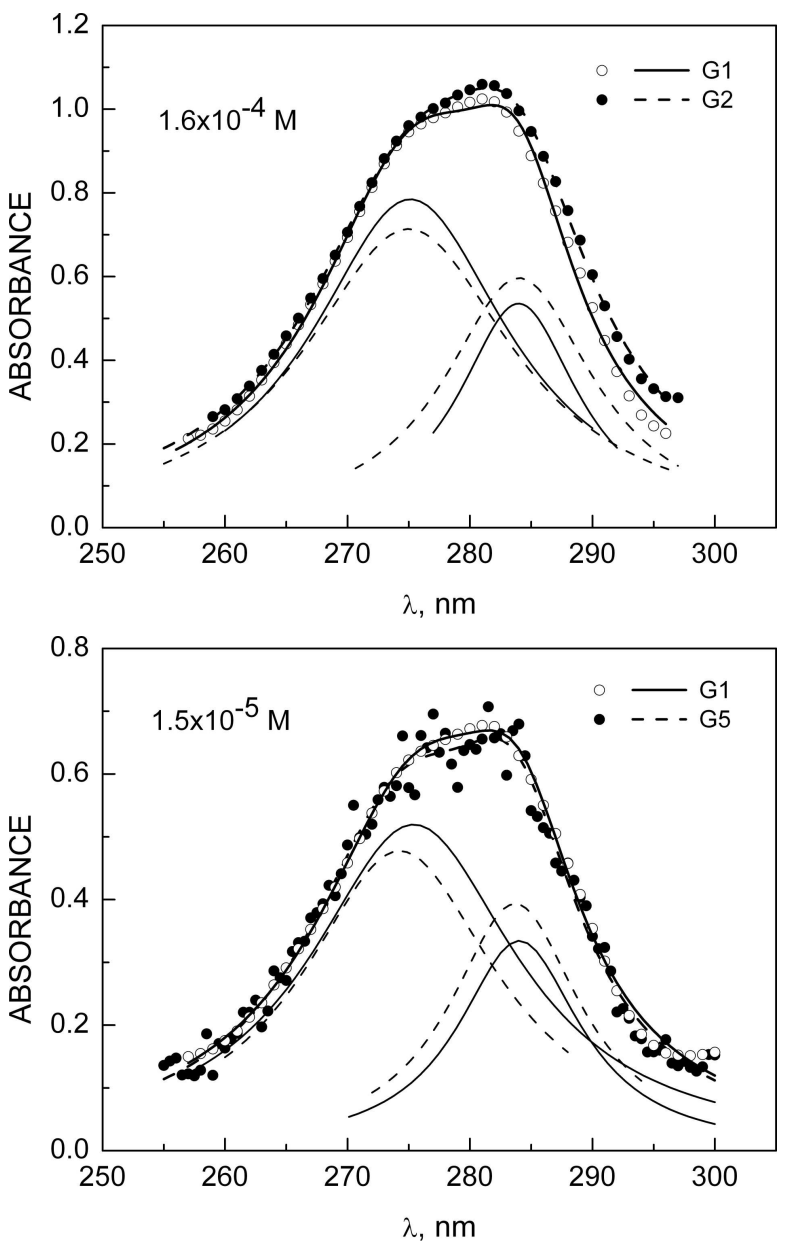

Fig. 6. Experimental (points) and decomposed (curves) absorbance spectra of amine terminated PPI dendrimer for generations G1, G2, and G5 at (a) higher and (b) lower molar concentrations.

nated PPI dendrimers will be the subject of further investigations.

\section{Acknowledgements}

Work has been supported by COST TD0802, COST MP0803, BalticGrid II, GridTechno, and LitGrid projects. Special thanks to Professor J.L. Serrano and Dr. M. Marcos for synthesized dendrimers.

\section{References}

[1] F. Vogtle, G. Richardt, and N. Werner, Dendrimer Chemistry: Concepts, Synthesis, Properties, Applications (Wiley-VCH, Weinheim, 2009) ch. 3.

[2] L. Pastor, J. Barbera, M. Mckenna, M. Marcos, R. Martin-Rapun, J.L. Serrano, G.R. Luckhurst, and A. Mainal, End-on and side-on nematic liquid crystal dendrimers, Macromolecules 37, 9386-9394 (2004).

[3] M. Franckevicius, R. Vaisnoras, M. Marcos, J.L. Serrano, R. Karpicz, and V. Gulbinas, Excited-state relaxation of dendrimers functionalized with cyanoazobenzene-type terminal groups, Chem. Phys. Lett. 485, 156-160 (2010).

[4] T. Pietsch, D. Appelhans, N. Gindy, B. Voit, and A. Fahmi, Oligosaccharide-modified dendrimers for templating gold nanoparticles: tailoring the particle size as a function of dendrimer generation and molecular structure, Colloids Surf. A 341, 93-102 (2009).

[5] M. Liu and J.M.J. Frechet, Design dendrimers for drug delivery, Pharm. Sci. Technol. Today 2, 393-401 (1999).

[6] Non-viral Gene Therapy: Gene Design and Delivery, eds. K. Taira, K. Kataoka, and T. Niidome (Springer Verlag, Tokyo, 2006) ch. 1.

[7] V. Butkus, D. Abramavicius, A. Gelzinis, and L. Valkunas, Two-dimensional optical spectroscopy of molecular aggregates, Lith. J. Phys. 50, 267-303 (2010).

[8] G. Seniutinas, L. Laipniece, J. Kreicberga, V. Kampars, J. Gražulevičius, R. Petruškevičius, and R. Tomašiūnas, Orientational relaxation of three different dendrimers in polycarbonate matrix investigated by optical poling, J. Opt. A 11, 034003-034009 (2009).

[9] B.-K. An, R. Mulherin, B. Langley, P. Burn, and P. Meredith, Ruthenium complex-cored dendrimers: Shedding light on efficiency trade-offs in dyesensitised solar cells, Org. Electron. 10, 1356-1363 (2009).

[10] T. Nakashima, N. Satoh, K. Albrecht, and K. Yamamoto, Interface Modification on $\mathrm{TiO}_{2}$ electrode using dendrimers in dye-sensitized solar cells, Chem. Mater. 20, 2538-2543 (2008).

[11] E. Badaeva, M.R. Harpham, R. Guda, özgün Süzer, Ch.-Qi Ma, P. Bauerle, T. Goodson III, and S. Tretiak, Excited-state structure of oligothiophene dendrimers: computational and experimental study, J. Phys. Chem. B 114, 15808-15817 (2010).

[12] A. Kulbickas, J. Tamuliene, L. Rasteniene, M. Franckevicius, R. Vaisnoras, M. Marcos, J.L. Serrano, B. Jaskorzynska, and L. Wosinski, Optical study and structure modelling of PPI liquid crystalline dendrimer derivatives, Photonics Nanostr. 5, 178-183 (2007).

[13] R.C. van Duijvenbode, M. Borkovec, and G.J.M. Koper, Acid-base properties of poly(propylene imine) dendrimers, Polymer 39, 2657-2664 (1998).

[14] M.J. Jasmine, M. Kavitha, and E. Prasad, Effect of solvent-controlled aggregation on the intrinsic emission properties of PAMAM dendrimers, J. Lumin. 129, 506-513 (2009).

[15] I.B. Rietveld and D. Bedeaux, The viscosity of solutions of poly (propylene imine) dendrimers in methanol, J. Colloid Interf. Sci. 235, 89-92 (2001).

[16] J. Gregorowicz and M. Luszczyk, Impact of water on the miscibility of DAB-dendr- $\left(\mathrm{NH}_{2}\right)_{64}$ and benzene, Macromolecules 40, 5966-5972 (2007). 
[17] C.F. Bohren and D. Huffman, Absorption and Scattering of Light by Small Particles (John Wiley, New York, 1983).

[18] R. Scherrenberg, B. Coussens, P. van Vliet, G. Edouard, J. Brackman, and E. De Brabander, The molecular characteristics of poly(propyleneimine) dendrimers as studied with small-angle neutron scattering, viscosimetry, and molecular dynamics, Macromolecules 31, 456-461 (1998).
[19] P. Laven, MiePlot program, available at www.philiplaven.com/MiePlot.htm

[20] M.F. Budyka, T.N. Gavrishova, and O.D. Laukhina, Spectral and photochemical properties of bifunctional compounds and their complexes. 2. Photocyclization of $\alpha, \omega$-bis(diphenylamino)alkanes to $\alpha, \omega$ di(carbazolyl)alkanes, Russ. Chem. Bull. 48, 14911496 (1999).

\title{
POLI(PROPILENO-IMINO) DENDRIMERŲ UV SPEKTRŲ SAVYBĖS
}

\author{
M. Franckevičius ${ }^{a}$, J. Tamuliené ${ }^{b}$, J. Babonas $^{c}$, I. Šimkiené ${ }^{\mathrm{c}}$, L. Rasteniené ${ }^{\mathrm{a}}$, A. Kulbickas ${ }^{\mathrm{a}}$, A. Iržikevičius ${ }^{\mathrm{a}}$, \\ R. Vaišnoras ${ }^{\text {a }}$ \\ ${ }^{a}$ Vilniaus pedagoginio universiteto Skystuju kristalu laboratorija, Vilnius, Lietuva \\ ${ }^{a}$ Vilniaus universiteto Teorinès fizikos ir astronomijos institutas, Vilnius, Lietuva \\ ${ }^{\mathrm{b}}$ Fiziniu ir technologijos mokslu centro Puslaidininkiu fizikos institutas, Vilnius, Lietuva
}

\section{Santrauka}

Ištirti įvairiu generaciju (G1 . .G5) poli(propileno-imino) (PPI) dendrimerų, funkcionalizuotu aminogrupemis, tirpalų dichlorometane sugerties spektrai. Nustatyta būdinga visiems ištirtiems junginiams dviguba juosta ties $270-290 \mathrm{~nm}$ ir jos kitimas priklausomai nuo dendrimeru generacijos ir tirpalo koncentracijos. Gauta, kad sugertis priklausè tiesiškai nuo dendrimero molinès koncentracijos tirpale, esant nedidelèms $1 \cdot 10^{-5} \mathrm{M}$ koncentracijoms. Aukštesnès generacijos (G3...G5) dendrimerų tirpalai pasižymejjo didele sklaida, kuri atitiko Rayleigh sklaidos dèsningumus. 